\title{
Linkage to Care for Suburban Heroin Users with Hepatitis C Virus Infection, New Jersey, USA
}

\section{Eda Akyar, Kathleen H. Seneca, Serra Akyar, Neal Schofield, Mark P. Schwartz, Ronald G. Nahass}

We identified a $41.4 \%$ prevalence of hepatitis $C$ virus, absence of HIV, and unexpectedly high frequency of hepatitis $C$ virus genotype 3 among suburban New Jersey heroin users 17-35 years of age during 2014-2015. Despite 2 clinicians prepared to engage these users, few were successfully linked to care and treated.

$\mathrm{H}$ epatitis $\mathrm{C}$ virus (HCV) infection is a major public health issue. Although persons born during 19461964 represent most of the population with chronic HCV infection, young persons (17-35 years of age) who inject drugs (PWID) now make up the second wave of HCV infection. Up to $90 \%$ of all new $\mathrm{HCV}$ infections worldwide are attributed to injection drug use; at least $75 \%$ of new $\mathrm{HCV}$ infections in the United States result from injection drug use $(1,2)$. In PWID, the prevalence of HCV is $60 \%$ $80 \%$ (3). Often, early age prescription opioid abuse leads to injection drug and heroin use (2). Escalating injection drug and heroin use has been associated with increasing $\mathrm{HCV}$ infection among young persons (2). An estimated $45 \%$ of young PWID in the United States are infected with HCV; the annual incidence is $8 \%-25 \%(2,4,5)$.

During 2006-2012 the incidence of acute HCV infections increased significantly among young people in nonurban areas of the United States (2). Among those persons, a $13 \%$ annual increase of acute HCV infection was reported in nonurban counties, a $170 \%$ increase over the course of 6 years (2). Young suburban heroin users have been described as the second wave of HCV infection in several US states, including Massachusetts and New York (5). New Jersey was not part of those initial reports. Our objective was to characterize $\mathrm{HCV}$ infection among young suburban heroin users in New Jersey and to evaluate linkage to care among this population.

Author affiliations: ID Care, Hillsborough, New Jersey, USA (E. Akyar, K.H. Seneca, S. Akyar, R.G. Nahass); University Medical Center at Princeton, Princeton, New Jersey, USA (K.H. Seneca, N. Schofield, M.P. Schwartz, R.G. Nahass); Rutgers University, New Brunswick, New Jersey, USA

(R.G. Nahass)

DOI: http://dx.doi.org/10.3201/eid2205.151980

\section{The Study}

During October 1, 2014-June 9, 2015, Princeton House, a psychiatric facility in suburban New Jersey with an active opioid detoxification program, instituted a new $\mathrm{HCV}$ screening program. As part of the standard of care, patients admitted for heroin detoxification were tested for HIV, $\mathrm{HCV}$, and hepatitis B virus infections. The average length of stay for opioid detoxification at Princeton House is 6 days. All patients positive for HCV antibody were clinically evaluated. HCV viral load and reflex genotypes (GTs) were obtained. Follow-up visits at Princeton House before discharge were performed by one of the authors (K.H.S. or R.G.N.) to counsel patients on results and the disease and to link patients to care by providing directions and appointments to HCV caregivers near patients' homes.

A total of 861 unique patients from 10 of 21 New Jersey counties were tested for HCV antibody; 374 (43.4\%) were positive. Most (573 [66.6\%]) patients were $17-35$ years of age. Of those, 237 (41.4\%) were HCV antibody positive. From this population, 187 patients were further evaluated; 50 patients refused evaluation or were discharged before evaluation. Women constituted $52.4 \%$. Races and ethnicities were 173 non-Hispanic white, 2 non-Hispanic black, 4 Hispanic, and 8 other.

HCV viral load was obtained for $172(92.0 \%)$ of the 187 patients; 15 patients were missed or not properly collected. For $32(18.6 \%)$ patients, viral load was undetectable. HCV GTs were obtained from 102 patients: 64 $(62.7 \%)$ were GT1a, 3 (2.9\%) were GT1b, 8 (7.8\%) were GT1 undefined, $1(1.0 \%)$ was GT2, and $26(25.5 \%)$ were GT3. Eight patients were identified with acute HCV. All patients who were HCV antibody positive were HIV antibody negative.

Of the 187 patients, $16(8.6 \%)$ had outpatient followup appointments, and $3(1.6 \%)$ started oral, direct-acting antiviral treatment. Two of the 3 patients failed to adhere to treatment regimen. One of the 16 patients spontaneously cleared infection before drug-treatment initiation. Two other patients returned for treatment but were denied prescriptions by insurance; all others failed to return for continued care.

\section{Conclusions}

Our study indicates that HCV was highly prevalent in young suburban heroin users attending an acute detoxification program that serves a wide geographic area, 
suggesting that New Jersey is participating in the second wave of HCV infection. Our study highlights the challenges of linking young PWID in suburban areas to care despite the effort of 2 clinicians with extensive HCV experience to engage patients in the care cascade. That most patients were women $(52.4 \%)$ and non-Hispanic white $(92.5 \%)$ probably reflects the demographic of persons seeking detoxification from heroin and coincides with demographics of other reports of young nonurban PWID in the United Sates (2).

The $25.5 \%$ (95\% CI $17 \%-34 \%$ ) prevalence of GT3 among this population of young suburban heroin users is more than twice the national average of $12 \%(6)$. This pattern of distribution suggests a closed network of injection drug users engaging in risky behavior that leads to $\mathrm{HCV}$ transmission.

Although HCV screening was easily attainable in Princeton House, linking patients to care was a challenge (Figure). Even with encouragement, only $16(8.6 \%)$ patients returned for in-office follow-up visits, and 2 started treatment. Patient follow-up after patients left Princeton House was a logistical challenge because of patient relocation and availability of transportation and communication. The program of acute detoxification at Princeton House simply withdrew patients from heroin under direct observation. Long-term patient management required additional treatment for patient addiction upon discharge, which was difficult to achieve. We were also limited by the absence of a care coordinator to assist with the linkage to care effort. Finally, some patients who came for outpatient treatment were denied treatment by payers because of the requirement of a clean drug test before treatment initiation or because patients did not have advanced liver disease, defined as Stage 3 or 4 . All create additional complexity, which delays treatment. Because we did not formally assess patients' psychosocial circumstances, our considerations for the reasons for failure to link to care are speculative and are currently being studied. We believe that difficulty in linkage to care represents an area where greater support will

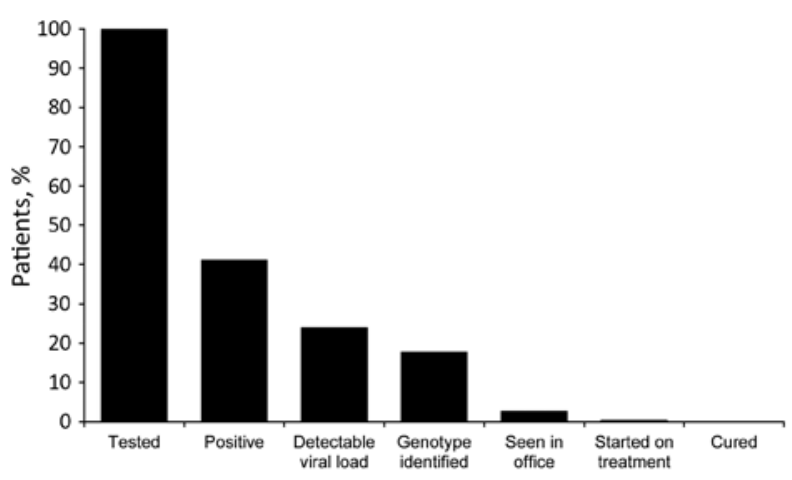

Figure. Cascade of care for suburban heroin users 17-35 years of age, New Jersey, October 1, 2014-June 9, 2015. be critical, such as through the use of case management, as was done with HIV care under the Ryan White program (7).

Also noteworthy is the absence of HIV in a population with a high percentage of injection drug use in a state with a high prevalence of HIV. Indiana's recent outbreak of HIV among young heroin users increases concern for the establishment of HIV in this network (8). To achieve success similar to that of HIV treatment in PWID, a coordinated program that includes committed case management services to help PWID navigate the complexity of accessing and maintaining treatment is likely to be needed. Further study to explore this and the ability to successfully treat this population is crucial to address the national HCV infection epidemic.

Finally, a misconception exists that PWID are poor candidates for treatment because of ongoing drug use, possible reinfection, and possible concomitant psychiatric or medical disorders (9). However, recent reports suggest that such patients can be successfully treated with newer therapies (10). Success in reducing HIV transmission among PWID during the past decade provides evidence that infected drug users can achieve adherence levels similar to persons who do not use drugs $(9,11)$. The potential for treatment as prevention was discussed by Hellard et al., who calculated the minimum number of patients within a network needed to be treated to reduce or eliminate transmission (10). Given the availability of easy-to-use therapy that is curative, linkage to care and treatment of HCV-infected PWID may be an important public health effort to prevent the continued spread of HCV. Further study is needed to identify predictors for successful linkage to care.

\section{Acknowledgments}

We thank Scott Holmberg for his encouragement and guidance.

This work was supported in part by a research grant from Investigator-Initiated Studies Program of Merck Sharp \& Dohme Corp.

Ms. Akyar works as a clinical research coordinator at ID Care. Her primary research interests are in infectious diseases.

\section{References}

1. Hellard M, Sacks-Davis R, Gold J. Hepatitis C treatment for injection drug users: a review of the available evidence. Clin Infect Dis. 2009;49:561-73. http://dx.doi.org/10.1086/600304

2. Suryaprasad AG, White JZ, Xu F, Eichler B, Hamilton J, Patel A, et al. Emerging epidemic of hepatitis $\mathrm{C}$ virus infections among young nonurban persons who inject drugs in the United States, 2006-2012. Clin Infect Dis. 2014;59:1411-9. http://dx.doi.org/ $10.1093 / \mathrm{cid} / \mathrm{ciu} 643$

3. Nelson PK, Mathers BM, Cowie B, Hagan H, Des Jarlais D, Horyniak D, et al. Global epidemiology of hepatitis B and hepatitis $\mathrm{C}$ in people who inject drugs: results of systematic reviews. Lancet. 2011;378:571-83. http://dx.doi.org/10.1016/S0140-6736(11)61097-0 
4. Page K, Morris MD, Hahn JA, Maher L, Prins M. Injection drug use and hepatitis $\mathrm{C}$ virus infection in young adult injectors: using evidence to inform comprehensive prevention. Clin Infect Dis. 2013;57(Suppl 2):S32-8. http://dx.doi.org/10.1093/cid/cit300

5. Koh HK, Valdiserri RO. Technical consultation. Hepatitis $\mathrm{C}$ virus infection in young persons who inject drugs; 2013 May [cited 2015 Nov 14]. https://www.aids.gov/pdf/hcv-and-young-pwidconsultation-report.pdf

6. Manos MM, Shvachko VA, Murphy RC, Arduino JM, Shire NJ. Distribution of hepatitis $\mathrm{C}$ virus genotypes in a diverse US integrated health care population. J Med Virol. 2012;84:1744-50. http://dx.doi.org/10.1002/jmv.23399

7. Spach D. Integrating hepatitis $C$ treatment in Ryan White clinics. Models \& steps [cited 2015 Nov 14]. https://careacttarget.org/ library/integrating-hepatitis-c-treatment-ryan-white-clinics-modelsand-steps.

8. Conrad C, Bradley HM, Broz D, Buddha S, Chapman EL,

Galang RR, et al. Community outbreak of HIV infection linked to injection drug use of oxymorphone-Indiana, 2015. MMWR Morb Mortal Wkly Rep. 2015;64:443-4.

9. McCance-Katz EF, Valdiserri RO, Hepatitis C. Virus treatment and injection drug users: it is time to separate fact from fiction. Ann Intern Med. 2015;163:224-5. http://dx.doi.org/10.7326/M15-0007

10. Hellard M, Rolls DA, Sacks-Davis R, Robins G, Pattison P, Higgs $\mathrm{P}$, et al. The impact of injecting networks on hepatitis $\mathrm{C}$ transmission and treatment in people who inject drugs. Hepatology. 2014;60:1861-70. http://dx.doi.org/10.1002/hep.27403

11. Aspinall EJ, Nambiar D, Goldberg DJ, Hickman M, Weir A, Van Velzen E, et al. Are needle and syringe programmes associated with a reduction in HIV transmission among people who inject drugs: a systematic review and meta-analysis. Int J Epidemiol. 2014;43:235-48. http://dx.doi.org/10.1093/ije/dyt243

Address for correspondence: Eda Akyar, ID Care, 105 Raider Blvd, Ste 101, Hillsborough, NJ 08844, USA; email: eda.akyar@gmail.com

\section{February 2015: Complicated Datasets}

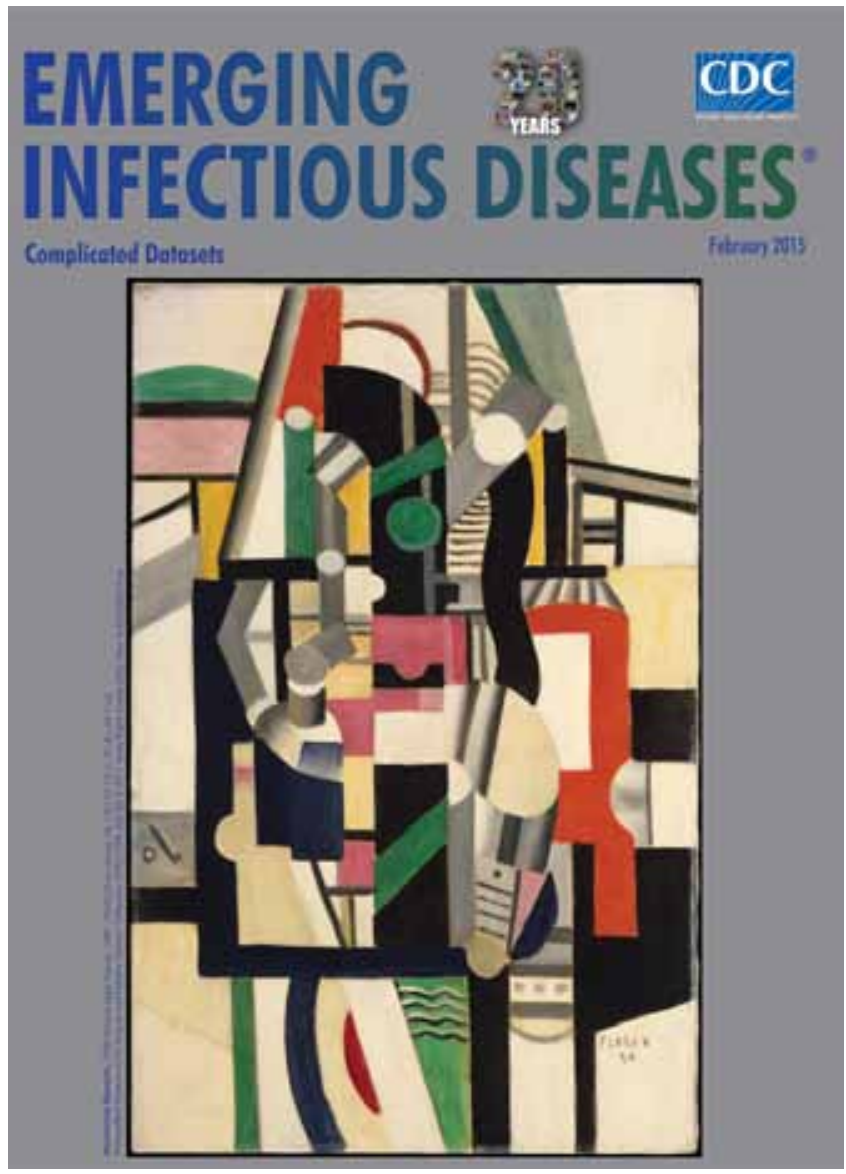

\section{Including:}

- Entry Screening for Infectious Diseases in Humans

- Timing of Influenza $\mathrm{A}(\mathrm{H} 5 \mathrm{~N} 1)$ in Poultry and Humans and Seasonal Influenza Activity Worldwide, 2004-2013

- Quantifying Reporting Timeliness to Improve Outbreak Control

- Tickborne Relapsing Fever, Bitterroot Valley, Montana, USA

- Simulation Study of the Effect of Influenza and Influenza Vaccination on Risk of Acquiring Guillain-Barré Syndrome

- Evidence for Elizabethkingia anophelis Transmission from Mother to Infant, Hong Kong

- Microbiota that Affect Risk for Shigellosis in Children in Low-Income Countries

- $\mathrm{pH}$ Level as a Marker for Predicting Death among Patients with Vibrio vulnificus Infection, South Korea, 2000-2011 